University for Business and Technology in Kosovo

UBT Knowledge Center

UBT International Conference

2012 UBT International Conference

Nov 2nd, 9:00 AM - Nov 3rd, 5:00 PM

\title{
Privatization, Liberalization of the Greek Telecommunication Sectors: a Social Cost - Benefit Analysis
}

Lorena Alikaj

University of Vlora, lorenaalikaj@yahoo.com

Matilda Veliu

University of Vlora, matildavl@yahoo.com

Follow this and additional works at: https://knowledgecenter.ubt-uni.net/conference

Part of the Business Commons

\section{Recommended Citation}

Alikaj, Lorena and Veliu, Matilda, "Privatization, Liberalization of the Greek Telecommunication Sectors: a Social Cost - Benefit Analysis" (2012). UBT International Conference. 48.

https://knowledgecenter.ubt-uni.net/conference/2012/all-events/48

This Event is brought to you for free and open access by the Publication and Journals at UBT Knowledge Center. It has been accepted for inclusion in UBT International Conference by an authorized administrator of UBT Knowledge Center. For more information, please contact knowledge.center@ubt-uni.net. 


\title{
Privatization, Liberalization of the Greek Telecommunication Sectors: a Social Cost -Benefit Analysis
}

\author{
Lorena Alikaj $^{1}$, Matilda Veliu ${ }^{2}$ \\ ${ }^{1}$ Departments of Economics, University "Ismail Qemali" of Vlora \\ Email:lorenaalikaj@yahoo.com \\ ${ }^{2}$ Departments of Economics, University "Ismail Qemali" of Vlora \\ Email:matildavl@yahoo.com
}

\begin{abstract}
With pressure from IMF and lately from the EU, privatization has become the key dimension of the world capital markets over the past three decades, and European Union has been the international leader in selling state-owned productive assets (national wealth) to the private sector (mostly to foreign firms) (Kallianiotis, 2007). The Greek Telecommunication industry as part of EU Telecommunication sector has experienced enormous changes in this period too. In this paper we have obtained the main economic indicators of the Greek Telecommunications industry, and report a social cost-benefit analysis of the privatization and liberalization of the Greek Telecommunications sector from 1998 up to 2009. Our results show that the net social benefits range from $62.85 \%$ to $145 \%$ of OTE's total annual revenues in 1998. This is a result well between the efficiency gains range obtained by Galal (Galal, et al., 1994). We can conclude that all agents seem to have benefited from the OTE privatization and the liberalization of the Greek telecommunications market.
\end{abstract}

Keywords: Public Goods, Cost Benefits Analysis, Government Regulation and Policy

\section{Introduction}

Telecommunication market until the decade of 1970's was functioned, all over the world, under monopoly and absolute protection (Wilson \& Zhou, 2001). In USA the telecommunication sector became private in 1970, while in Grand Britain and Japan it started around 1980. The procedure of privatization in European countries started in 1984 and completed in 1998 (Parker, 2004). In Greece it began in 1990.

With pressure from IMF and lately from the EU, privatization has become the key dimension of the world capital markets over the past three decades, and European Union has been the international leader in selling state-owned productive assets (national wealth) to the private sector (mostly to foreign firms) (Kallianiotis, 2007). This is so because the states had historically taken a major direct role in the economy of all European countries, due to security, social policy, control of the enterprises, ownership of the national assets (wealth) by the nation, and prevention of social inequality. During the Great Depression (early 1930s), many productive assets were shifted to state ownership as failing enterprises were taken over by governments in the Western Europe. In the Eastern Europe, due to the socialist system, all enterprises ended up in the hands of the government. The last major expansion of state control in Europe was the nationalization of the banks in France at the outset of the Mitterrand administration in Economy (Walter, et al., 2000).

External global pressures such as the globalization of trade and the emergence of new global networks of firms are the background for the formation of a European policy in the sector. The policy is carried out of directives that are approved by the Council of Ministers. The main thrust of EU Telecommunication Policy is to separate services from infrastructure provision and to encourage competition in service provision. Value added (since 1991), data (since 1992), satellite communication (until 1994) and mobile telephone services (until 1996) are fully liberalized with some countries, as there were others, like Greece that did not fulfilled the requirements until 2003. The complete deregulation of the Greek telecommunication market provoked a successive entry of new telecommunications enterprises. Both the liberalization and the privatization program took place on a basis of gradual implementation.

Hellenic Telecommunications Organization (OTE) is a full-service telecommunications group and the leading provider of fixedline voice telephony and internet access services in Greece. Discussions on the privatization of OTE had started as early as 1992, but were blocked due to political discord and the opposition of OTE trade unions. In April 1996 the Government began the privatization of OTE through public subscription and private placement of a minority $7.5 \%$ of the company's share capital. The process of (regular) public offerings through the Athens Stock Exchange took place for a short/middle term period and the sta te's share has progressively decreased. The plan of a strategic investor has led to the agreement with the German company 'Deutsche 
Telecom' (2008). At the moment the Greek State owns directly a 17.93\% stake and indirectly (share of IKA and DEPA AE) $25 \%$ and one auction, equally to the share of Deutsche Telecom (OTE SEC filings, 2009). Concerning the necessity and the pace of the privatization procedure, it should be mentioned that these questions were at the discretion sphere of the Greek government. The aim of the study was to evaluate the social welfare impact of privatization and liberalization of the Greek telecommunications sector. The social value of the privatization reform depends on the welfare of the different economic grou ps (consumers, producers and government, etc) potentially affected by it. Privatization offers substantial opportunities for private industry buyers or private shareholders, but a key concern is whether such gains come at the expense of other groups, resulting in aggregate welfare losses. In particular, we wanted to infer how the aggregate social gain (cost) is distributed among these different economic groups.

We have used the same methodology a difference-in-differences approach. The essence of this approach is to construct (simulate) for each variable a counterfactual behavior correspondent to the hypothetical scenario of no reform in the telecommunications sector. Therefore, the impact of the reform is isolated by the difference between the effective (observed) and simulated values before and after the implementation of the reform. The change in the aggregate welfare is found by the sum of the net changes in the welfare levels of the individual groups. Until now, there is little data addressing the Greek telecommunications' reforms economic impact. Therefore, the findings of this study can provide more data about the sector and the impact of privatization.

\subsection{Methodology}

The social cost benefit methodology. The methodology was first set out by (Jones, et al., 1990), and then applied in (Galal, et al., 1994) to 12 case studies - mostly from infrastructure, airlines/logistics and telecoms sectors. They find that divestiture substantially improved economic welfare in 11 of the 12 cases, with the main drivers being an increase in investment, improve d productivity, more rational pricing policies, increased competition and effective regulation.

Using the same methodological approach (Jones, et al., 1990) confirms the positive welfare effect in a study of privatizations in Cote D'Ivoire. Several SCBA's exist on the UK electricity sector, including (Newberry, et al., 1997)- who find positive welfare implications from the privatization of the Central Electricity Generating Board, but a skewed distribution of benefits in fav or of producers (Green, et al., 1998) and (Domah, et al., 2001).

In contrast to most empirical research on privatization, liberalization, and regulation it focuses on welfare changes for different agents and not just on productivity and profitability or other business performance indicators. The me thodology of VJT (Vogelsang, Tandon, Jones) is a social cost-benefit analysis, involving a counterfactual scenario. This is needed to compare the performance of the company after divestiture with what that performance would have been under continued public ownership. We think that this approach is better than most empirical privatization research that simply compares data 'before' and 'after' privatization (usually for a limited number of years), and hence scarcely controls for a number of exogenous changes in the environment, including demand and technical progress.

The crucial step in any ex ante cost-benefit analysis is the calculation of the welfare change as a difference between the welfare levels in the do-nothing project scenario and in the forecasts under the implemented project scenario. A cost benefit analysis starts with a measurement of the quantitative impact on the economy with the project (privatization of OTE and liberalization of the Greek telecommunications market) relative to the counterfactual of the economy without the project (public OTE operating in an entry protected telecommunications market).

The economic impact can be assessed in efficiency terms by analyzing productive efficiency (determining cost differences between the actual and counterfactual scenarios) as well as allocate efficiency (whether there is a Pareto superior welfare equilibrium). Following literature (Newberry, et al., 1997), and (Domah, et al., 2001)), we will ignore allocate efficiency for reasons of simplicity, as standard measures of deadweight loss seem to be relative small given the size of annual productive efficiency gains.

The impact on social welfare is made up of two components. The first component is the difference between the social value of the firm under private operation (welfare after the firm's sale) and the social value of the firm under government operation (welfare of the company under government ownership). The second component is the sale value itself. Privatization would be considered as socially worthwhile if the resulting estimated impact is positive.

The overall change in welfare can be written as (Jones, et al., 1990)

$$
\Delta W=V s p-V S G+(\lambda G-\lambda P) Z
$$

Where $\Delta W$ is the total change in social welfare, $V \boldsymbol{S P}$ is the social value under private operation, $V \boldsymbol{S} \boldsymbol{G}$ is the social value under continued government operation, $Z$ is the sale price, and $\lambda G$ and $\lambda P$ are shadow multiplier on government and private funds. Unless these shadow multipliers differ, the sale price is a straightforward transfer of funds from private investors to government with no implications for aggregate welfare. For the initial assessment we thus assume no difference between these multipliers and focus on the first two terms of equation (1). The basic equation can be extended in various ways, e.g. by introducing a 
welfare weight for the increase in the welfare of the rest of the world, in cases where the net beneficiaries are foreign subjects. The authors do not apply a shadow price to public revenue (or to other items).

The social value of the privatization reform depends on the welfare of the groups potentially affected by it. These are the consumers, the government and any other shareholders before privatization, the buyers, employees, competitors, and the taxpayers. In fact, the downsizing process at OTE was rather consensual, thanks to generous severance pay. Moreover, OTE workers were well qualified and easily absorbed in other companies, including those working as subcontractors of some OTE services, and the competitors. As a result, the workers' welfare change of privatization is rather neutral. So, we have exclu ding this group from the analysis. Under the same assumption the distributional impact can be simplified to:

$$
\Delta W=\Delta \text { Cons }+\Delta \operatorname{Prod}+\Delta G o v
$$

Where $\Delta$ Cons is the change in consumer welfare, $\Delta$ Prod is the change in producer welfare (equivalent to shareholder benefits), and $\triangle G o v$ is the change in government welfare.

Privatization offers substantial opportunities for private industry buyers or private shareholders, but a key concern is whet her such gains come at the expense of other groups, resulting in aggregate welfare losses. (Jones, et al., 1990) Jones calls this the "fundamental trade-off of divestiture" - privatization might provide improvements in managerial incentives and technical efficiency, but might also lead to allocate inefficiencies and the misuse of market power. Als o, sometimes the sales price received by the government might not adequately reflect intrinsic asset values.

Following this approach, and in order to estimate the social welfare impact of OTE privatization and liberalization of its markets, we only need to estimate the difference between the actual path of costs under private ownership and the counterfactual path of costs. In the counterfactual scenario we have to determine what would have happened if privatization did not take place and the telecommunications market were still protected from entry of new firms.

To evaluate the cost savings due to efficiency gains we deduct the controllable costs (operating costs excluding depreciation and amortization) under private operation from counterfactual controllable costs. Studying the distribution of gains, enable us to measure the restructuring impact overall economic agents and to evaluate the "fairness" of the achieved allocation.

Following the literature (Galal, et al., 1994) the consumers' welfare change is assessed through the difference between private and counterfactual revenues (Domah, et al., 2001). Revenues can be obtained by summing operating profits (pre-tax), the income/expenses from financial activities, depreciation and net operating costs.

The profits' difference (less differences in tax) in actual and counterfactual scenarios measures the welfare gains (or losses) of producers. Finally, to evaluate the gains (or losses) of the government we calculate the difference between actual and counterfactual taxes.

\section{Factual and Counterfactual analysis}

\subsection{What happened: The factual}

The traditional argument in favor of privatization rests on the idea that internal (productive) efficiency should improve with the change in ownership, just because the slack allowed by the multi-goal nature of a state owned enterprise would disappear when the profit maximization motive emerges as the only objective of a privately owned firm. From this it follows that, all other things being equal, unit costs faced by the firm should jump down or decline steadily after privatization.

Following the methodology described above, and in order to estimate the social welfare impact of OTE privatization and liberalization of its markets, we only need to estimate the difference between the actual path of costs under private ownership and the counterfactual path of costs. For this reason we focused now on the actual path of cost under private ownership to se e the development of operating costs and the unit variable cost in time span 1997-2009.

The Table 1 covered by our dataset allows us to analyze the behavior of labor costs, other operating costs and depreciation a s a share of annual revenues. In the Figure 1 we can see the time path of (labor costs/sales) and (other operating costs/sales), together with the evolution of the aggregate datum, namely (labor costs + other operating costs/sales) variable unit cost. A lso, by added this, the depreciation and amortization costs/sales we can derive the total unit operating costs.

\section{Table 1}

Variable unit cost and total unit cost trend 1997-2009

(In percentages)

\begin{tabular}{|c|c|c|c|c|c|c|c|c|c|c|c|c|c|}
\hline Year & $\begin{array}{c}199 \\
7\end{array}$ & $\begin{array}{c}199 \\
8\end{array}$ & $\begin{array}{c}199 \\
9\end{array}$ & $\begin{array}{c}200 \\
0\end{array}$ & $\begin{array}{c}200 \\
1\end{array}$ & $\begin{array}{c}200 \\
2\end{array}$ & $\begin{array}{c}200 \\
3\end{array}$ & $\begin{array}{c}200 \\
4\end{array}$ & 2005 & $\begin{array}{c}200 \\
6\end{array}$ & $\begin{array}{c}200 \\
7\end{array}$ & $\begin{array}{c}200 \\
8\end{array}$ & $\begin{array}{c}200 \\
9\end{array}$ \\
\hline labor costs/sales & 28.0 & 23.6 & 20.8 & 23.0 & 20.5 & 20.3 & 22.0 & 23.7 & 24.2 & 21.4 & 18.2 & 18.2 & 19.9 \\
\hline
\end{tabular}




\begin{tabular}{|l|c|c|c|c|c|c|c|c|c|c|c|c|c|}
\hline other costs/sales & 25.9 & 32.6 & 34.5 & 39.2 & 37.5 & 39.7 & 38.8 & 44.3 & 56.54 & 42.0 & 46.7 & 46.4 & 44.1 \\
\hline $\begin{array}{l}\text { total variable costs/sales } \\
\begin{array}{l}\text { Depreciation /amortization } \\
\text { costs/sales }\end{array}\end{array}$ & 53.9 & 56.2 & 55.3 & 62.2 & 58.0 & 60.0 & 60.8 & 68.0 & 80.74 & 63.4 & 64.9 & 64.6 & 64.0 \\
\hline $\begin{array}{l}\text { Total operating costs/sales } \\
\text { Toln }\end{array}$ & 64.9 & 10.6 & 12.0 & 14.0 & 14.5 & 16.3 & 18.5 & 19.7 & 19.3 & 18.6 & 18.5 & 18.9 & 19.3 \\
\hline \hline
\end{tabular}

Source: Data research

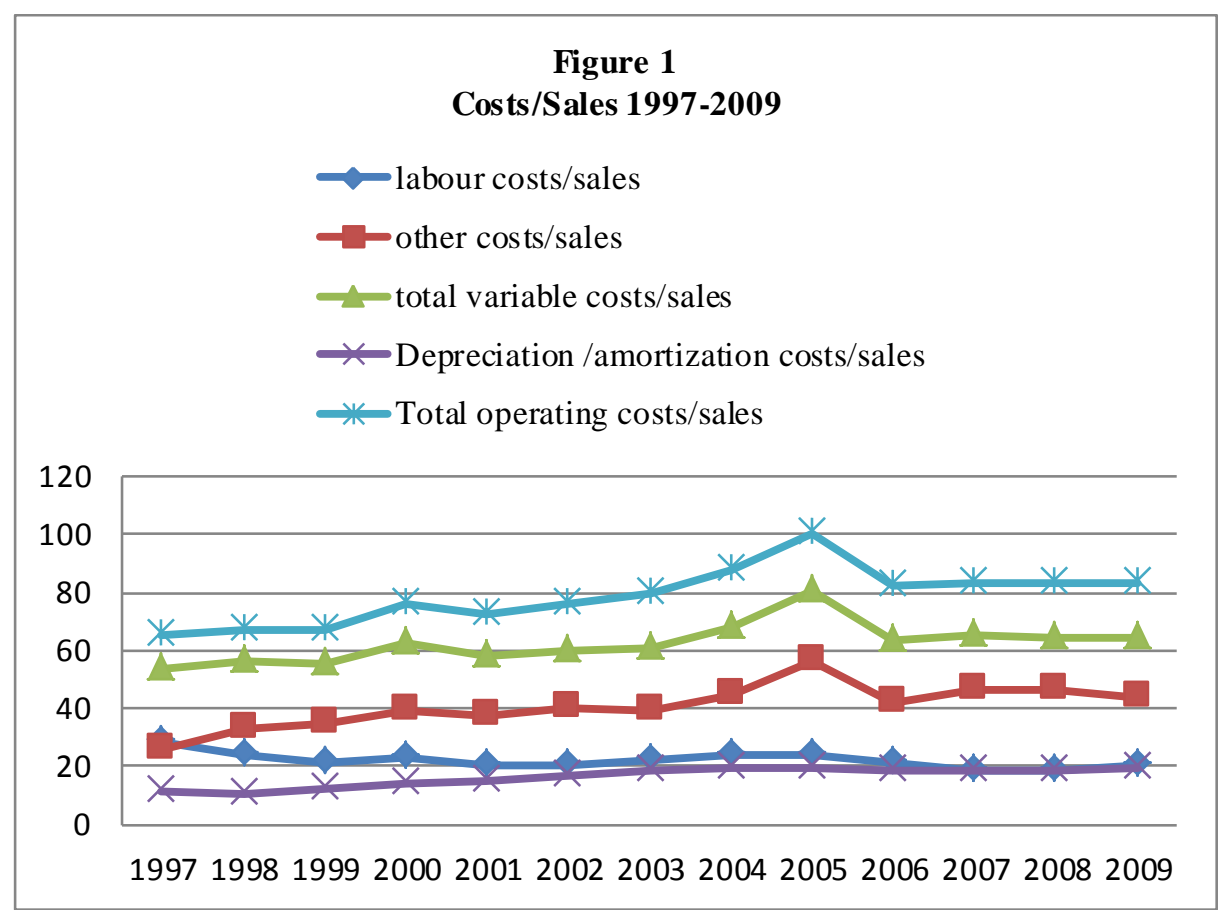

Some patterns clearly emerge here: there is a negative trend in the path of labor costs over sales, while the trend is positive for other operating costs. This could be due to technological phenomena such as the increased reliance on outsourcing and can tell us an increase in productivity of the organization after partial privatization. If we focus on total variable cost over sales we can see that there is a positive trend here but if we compare it with labor and other costs, the variable cost stay more stable in ye ars except in 2005 where this cost reached the peak $80,74 \%$ of total sales. It should be noted that this result is mainly due to the implementation of the International Accounting Standards for the first time in 2005 and the total cost of the personnel's voluntary retirement program, which came up to €939.6 million.

In our analysis we have put together the depreciation and amortization costs because in OTE Group financial reports the y were consolidated under one item. In our analysis we see that these costs have been increased year-to -year. These costs have reached the peak in 2004 about 19, 7\% over sales and the increase was mainly attributable to the inclusion of Romtelecom's depre ciation expenses of Euro 168.4 million for the full year in 2004, as well as to increased depreciation expense from Cosmote, Globul, Hellas Sat and Cosmofon, and partially offset by a decrease in depreciation expense of OTE. Also, the increase in depreciat ion expense was mainly due to additions of fixed assets in connection with the upgrading of the capability of others fixed line a nd mobile networks.

If we add to these costs the total variable cost we can take total operating costs per units. From the dat a on Table 16 above we can see clearly that this cost has been increased year -to - year except the 2005 year where the total operating costs have outperform the total revenue for the same reason mention above. 


\subsection{What would have happened: the counterfactual}

The focus of analysis is therefore on costs - including operating costs - and their translation into public and welfare generation. To build counterfactuals scenarios we have based our analysis on the historical performance of the company prior and after privatization. Base on the methodology to evaluate the cost savings due to efficiency gains we deduct the controllable costs under private operation from counterfactual controllable costs. We calculate the counterfactuals controllable cost $=$ counterfactual operating costs - counterfactual depreciation costs.

We can use the immediate post-privatization year as the base year, but because the COSMOTE began its commercial operations in April 1998 we have used the 1998 as a base year and not the 1997, and therefore we assume various counterfactual costs' declines.

Because of the lack of the data of the period before privatization, in the table below we have calculated two ratio one is to tal operating costs oversales and the other is a profitability ratio that is calculated as Net profit before taxes over own capital. The financial figures of OTE show a significant improvement during the pre-privatization period (1989-1996). More specifically, the profitability of the Organization increases from 12.7\% in 1989 to 40, 7\% in 1996, while the operation expenditure over sales has been reduced year - to - year from 83,6\% in 1989 to $61,3 \%$ in 1996 and this was the reason why we have assumed various counterfactual costs' declines.

Table 2

The development of operating performance of OTE prior privatization 1989-1996

\begin{tabular}{|c|c|c|c|c|c|c|c|c|}
\hline Year & $\mathbf{1 9 8 9}$ & $\mathbf{1 9 9 0}$ & $\mathbf{1 9 9 1}$ & $\mathbf{1 9 9 2}$ & $\mathbf{1 9 9 3}$ & $\mathbf{1 9 9 4}$ & $\mathbf{1 9 9 5}$ & $\mathbf{1 9 9 6}$ \\
\hline operation expenditure / sales & 83.6 & 81.6 & 79.3 & 76.0 & 70.0 & 70.5 & n.a & 61.3 \\
\hline net profit before tax / own capital & 12.7 & 16.5 & 19.5 & 23.6 & 32.7 & 39.1 & n.a & 40.7 \\
\hline \hline
\end{tabular}

Source: OTE Group balance sheet

If we assume that the organization was operating under state ownership and the organization was still protected from new entries the operating performance in the future (after-privatization period) will follow the same trend as in the pre-privatization period. Base on this assumption, we calculate five possible counterfactual controllable costs scenarios and we assume that would be 0,2 , 4, 6, and 8 per cent for counterfactual controllable costs decline. We could use other counterfactuals, but for simplicity and comparability with literature we do not explore other scenarios.

We stated before that public utilities tend to invest more, and that it was expected that OTE's investment would be greater in counterfactual scenario, but for reasons of simplicity and admitting a possible pro-public impact in the results, we assume that the firm would invest the same amount in the actual and counterfactual scenarios. So, depreciation charges will be the same for actual and counterfactual scenarios.

Also non-controllable costs (other income/expenses which came from financial activities) are assumed to reach the same magnitude in actual and counterfactual scenarios.

In this study we assume that the demand growth of all OTE telecommunications services is the same in actual and counterfactual scenarios. Counterfactual profits (pre-tax) are calculated annually using the base year rate of return on working assets. The base year rate of return is $31.1 \%$. We assume that in the immediate post-privatization year actual and counterfactual working capital as sets are equal and then counterfactual working capital as sets grow at the actual demand growth rate.

Counterfactual total revenues result from the sum of counterfactual profits, counterfactual controllable and non-controllable costs and counterfactual depreciation charges.

Counterfactual taxes are estimated using a tax rate defined as the quotient of actual income taxes paid over operating profits. This tax rate is applied to the counterfactual operating profit in order to calculate counterfactual taxes.

Because of the lack of data and because of the difficulty to calculate the social welfare value of actual and counterfactuals scenarios we calculate the social welfare impact of partial privatization using the equation (2) in methodology part.

$$
\Delta W=\Delta \text { Cons }+\Delta \operatorname{Prod}+\Delta G o v
$$

The annual values estimated were aggregated on a present-value basis using different discount rates. The reference discount rate should be the Treasury's preferred discount rate in the data period (Domah, et al., 2001). We used discount rates varying from as 
low as 3 per cent to as high as 10 per cent. This procedure accounts for the sen sitivity of the results and help to evaluate the robustness of the welfare estimates.

Actual total revenues less the counterfactual total revenues are summed on a present value basis to give us the consumer's welfare change.

Actual profits (pre-tax) less counterfactuals profits (pre-tax) are summed on a present value basis to give us the producer's welfare change.

Actual taxes less counterfactual taxes are summed on a present value basis to give us the government's welfare change.

The counterfactual scenarios differ from the factual from the year 1998 onwards. For the terminal value, the basic methodology is a simple perpetuity calculation. As the terminal value period can carry significant weight in the calculation of net prese nt costs or benefits, the assumption on the long-term development of cost differences is critical. In the absence of perfect foresight, there are equally valid reasons to believe that the differential might narrow or widen over time. Some previous SCBA's (Newberry, et al., 1997); (Bordman, 2007)) hence assume cost differentials to remain constant in the future, so it is assumed that any existing cost differential between factual and counterfactual in 2009 (the last year of historic data) will be reduced to zero by 2010 in four equal steps, with no cost differences at all arising in the terminal value period.

Following the assumption underlined above we have calculated all the results for the counterfactuals scenarios which are necessary to estimate the social welfare change resulting by partial privatization and liberalization of Greek Telecom. All data are gathered on the Table 3 below.

\section{Table 3}

The development of results for counterfactuals performance if OTE S.A would have been under state ownership for time period 1998-2009

(in million euro)

\begin{tabular}{|c|c|c|c|c|c|c|c|c|c|c|c|c|}
\hline Year & 1998 & 1999 & 2000 & 2001 & 2002 & 2003 & 2004 & 2005 & 2005 & 2007 & 2008 & 2009 \\
\hline $\begin{array}{c}\text { Counterfactual } \\
\text { working assets }\end{array}$ & 1406,8 & 1642,6 & 1818,4 & 2059,2 & 2178,5 & 2484,9 & 2621,3 & 2766,4 & 2977,0 & 3195,6 & 3239,8 & 3039,2 \\
\hline $\begin{array}{c}\text { Counterfactuals } \\
\text { ope rating profits }\end{array}$ & 437,5 & 510,8 & 565,5 & 640,4 & 677,5 & 772,8 & 815,2 & 860,4 & 925,8 & 993,8 & 1007,6 & 945,2 \\
\hline $\begin{array}{r}\text { Counterfactual } \\
\text { income taxes }\end{array}$ & 161,8 & 194,1 & 215,8 & 231,6 & 261,7 & 312,0 & 187,5 & 189,3 & 361,1 & 328,0 & 294,2 & 460,1 \\
\hline $\begin{array}{r}\text { Counterfactual total } \\
\text { re ve nue for } 0 \% \\
\text { decline in operating } \\
\text { cost }\end{array}$ & 2240,6 & 2780,3 & 3106,4 & 3969,7 & 4198,2 & 4750,9 & 5473,4 & 6355,4 & 5682,3 & 6158,8 & 6570,9 & 6148,6 \\
\hline $\begin{array}{r}\text { Counterfactual total } \\
\text { re ve nue for } 2 \% \\
\text { decline in operating } \\
\text { cost } \\
\end{array}$ & 2209,9 & 2745,0 & 3062,5 & 3923,3 & 4147,5 & 4692,4 & 5404,3 & 6268,7 & 5609,1 & 6078,4 & 6489,8 & 6073,5 \\
\hline $\begin{array}{r}\text { Counterfactual total } \\
\text { re ve nue for } 4 \% \\
\text { decline in operating } \\
\text { cost }\end{array}$ & 2180,5 & 2711,1 & 3020,3 & 3878,7 & 4098,6 & 4636,0 & 5337,9 & 6185,4 & 5538,8 & 6001,1 & 6411,8 & 6001,4 \\
\hline $\begin{array}{r}\text { Counterfactual total } \\
\text { re ve nue for } 6 \% \\
\text { decline in operating } \\
\text { cost }\end{array}$ & 2118,2 & 2678,5 & 2979,7 & 3835,8 & 4051,7 & 4581,9 & 5274,0 & 6105,2 & 5471,0 & 5926,7 & 6336,7 & 5931,9 \\
\hline $\begin{array}{l}\text { Counterfactual total } \\
\text { re venue for } 8 \% \\
\text { decline in operating } \\
\text { cost }\end{array}$ & 2124,8 & 2647,1 & 2940,6 & 3794,5 & 4006,5 & 4529,7 & 5212,4 & 6028,0 & 5405,8 & 5855,0 & 6264,5 & 5865,0 \\
\hline $\begin{array}{r}\text { Government's } \\
\text { welfare change } \Delta G\end{array}$ & 200,3 & 178,0 & 187,0 & 37,2 & 42,7 & 65,9 & $-66,7$ & $-156,8$ & 80,4 & 53,8 & $-48,0$ & $-80,1$ \\
\hline $\begin{array}{r}\text { Producer's welfare } \\
\text { change } \Delta P\end{array}$ & 341,2 & 290,2 & 302,8 & 65,6 & 68,0 & 97,5 & $-222,7$ & $-727,6$ & 124,7 & 107,2 & $-115,6$ & $-84,4$ \\
\hline $\begin{array}{r}\text { Consumer's welfare } \\
\text { change } \Delta \mathrm{C} 1 \text { (under } \\
0 \% \text { cost decline } \\
\text { scenario) }\end{array}$ & 541,5 & 468,2 & 489,8 & 102,8 & 110,7 & 163,4 & $-289,4$ & $-884,4$ & 205,1 & 161,0 & $-163,6$ & $-164,5$ \\
\hline $\begin{array}{r}\text { Con sumer's welfare } \\
\text { ch ange } \Delta \mathrm{C} 1 \text { (under } \\
2 \% \text { cost decline } \\
\text { scenario) } \\
\end{array}$ & 572,2 & 503,5 & 533,7 & 149,2 & 160,9 & 221,9 & $-220,3$ & $-797,7$ & 278,3 & 241,4 & $-82,5$ & $-89,4$ \\
\hline $\begin{array}{l}\text { Consumer's welfare } \\
\text { change } \Delta \mathrm{C} 1 \text { (under }\end{array}$ & 601,6 & 537,4 & 575,9 & 193,8 & 210,3 & 278,3 & $-153,9$ & $-714,4$ & 348,6 & 318,7 & $-4,5$ & $-17,3$ \\
\hline
\end{tabular}




\begin{tabular}{|c|c|c|c|c|c|c|c|c|c|c|c|c|}
\hline $\begin{array}{r}4 \% \text { cost decline } \\
\text { scenario) }\end{array}$ & & & & & & & & & & & & \\
\hline $\begin{array}{r}\text { Consumer's welfare } \\
\text { change } \Delta \mathrm{C} 1 \text { (under } \\
6 \% \text { cost decline } \\
\text { scenario) } \\
\end{array}$ & 663,9 & 570,0 & 616,5 & 236,7 & 257,2 & 332,4 & $-90,0$ & $-634,2$ & 416,4 & 393,1 & 70,6 & 52,2 \\
\hline $\begin{array}{r}\text { Consumer's welfare } \\
\text { change } \Delta \mathrm{C} 1 \text { (under } \\
8 \% \text { cost ) }\end{array}$ & 657,3 & 601,4 & 655,6 & 278,0 & 302,4 & 384,6 & $-28,4$ & $-557,0$ & 481,6 & 464,8 & 142,8 & 119,1 \\
\hline
\end{tabular}

\section{Empirical results and concluding remarks}

Given our as sumptions on counterfactual cost fall, we then calculate the efficiency gains of privatization and liberalization relative to each counterfactual public scenario. These results are shown in Table19, where three different discount rates were used

Table 4

Net efficiency gains

(in millions of euro)

\begin{tabular}{|l|ccc|}
\hline $\begin{array}{c}\text { Counterfactual } \\
\text { cost decline }\end{array}$ & \multicolumn{3}{|c}{ Discount rate } \\
\hline & $3 \%$ & $6 \%$ & $10 \%$ \\
$0 \%$ decline & 1748,77 & 2004,46 & 2145,83 \\
$2 \%$ decline & 2354,92 & 2447,99 & 2518,15 \\
$4 \%$ decline & 2938,72 & 2939,60 & 2917,05 \\
$6 \%$ decline & 3533,89 & 3445,73 & 3333,96 \\
$8 \%$ decline & 4039,43 & 3865,81 & 3668,08 \\
\hline
\end{tabular}

For each discount rate we then distribute net efficiency gains to the three defined types of agents. Net efficiency gains dis tributed to the government and to producers do not vary with counterfactual scenarios. This is a result of the methodology used to derive the distributional effects, where revenues are calculated as a residual, summing operational profits, depreciation and net operational costs.

All counterfactuals scenarios yield comparable results as set out in the Table 4 above. Across the five scenarios and the three different discount rates, the estimated net present value (NPV) of social net benefits from partial -privatization of OTE is between $€ 1748,77$ millions to $€ 4039,43$ millions in 1998 money. The total annual sales of OTE in 1998 were $€ 2782,1$ millions so the net social benefit range from $62,85 \%$ (in the strong pro-public scenario) to $145 \%$ (in the strong pro-privatization scenario) of 1998 annual total OTE revenues. This is a result well between the efficiency gains range obtained by Vogelsang (Galal, et al., 1994). These authors calculated that BT's privatization process generated annualised un-weighted benefits of 12 percent of the pre-divestiture annual sales (and annualised socially weighted benefits of 9.4 percent of these sales). Given their social costbenefit analysis results, they concluded that privatization was a success.

In the same study, these authors studied two more telecommunications privatizations cas es occurred respectively in Chile and Mexico. The privatizations of Compañía de Teléfonos de Chile (CTC) in Chile and Teléfonos de México (Telmex) in Mexico were analysed. The privatization results for Telmex indicate a net weighted loss of -13.3 percent of pre-divestiture annual sales. By contrast, CTC privatization resulted in a success with a net gain of 142.5 percent of annual pre-divestiture annual sales. Having estimated the total change in welfare due to partial-privatization, we now calculate how the effects are distributed among consumers, producers and government.

\section{Table 5}

Distribution of net efficiency gains from privatisation and liberalis ation (In millions Euro)

\section{Discount rate}


0\% cost decline (strong pro-public scenario)

\begin{tabular}{lrrr} 
Consumers & 874,64 & 1035,86 & 1093,58 \\
Government & 505,84 & 510,70 & 510,35 \\
Producers & $\underline{368,29}$ & 457,90 & $\underline{541,90}$ \\
Total & $\mathbf{1 7 4 8 , 7 7}$ & $\underline{\mathbf{2 0 0 4 , 4 6}}$ & $\underline{\mathbf{2 1 4 5 , 8 3}}$ \\
\hline
\end{tabular}

$2 \%$ cost decline (pro-public scenario)

\begin{tabular}{lrrr} 
Consumers & 1480,79 & 1479,39 & 1465,90 \\
Government & 505,84 & 510,70 & 510,35 \\
Producers & $\underline{368,29}$ & 457,90 & $\underline{541,90}$ \\
Total & $\underline{\mathbf{2 3 5 4 , 9 2}}$ & $\underline{\mathbf{2 4 4 7 , 9 9}}$ & $\mathbf{2 5 1 8 , \mathbf { 1 5 }}$ \\
\hline
\end{tabular}

$4 \%$ cost decline (central case scenario)

\begin{tabular}{lrrr} 
Consumers & 2064,59 & 1971,00 & 1864,80 \\
Government & 505,84 & 510,70 & 510,35 \\
Producers & 368,29 & 457,90 & $\underline{541,90}$ \\
Total & $\underline{\mathbf{2 9 3 8 , 7 2}}$ & $\underline{\mathbf{2 9 3 9 , 6 0}}$ & $\mathbf{2 9 1 7 , 0 5}$ \\
\hline
\end{tabular}

6\% cost decline ( moderate pro-privatization scenario)

\begin{tabular}{lrrr} 
Consumers & 2659,76 & 2477,13 & 2281,71 \\
Government & 505,84 & 510,70 & 510,35 \\
Producers & 368,29 & $\underline{457,90}$ & $\underline{\mathbf{5 4 1 , 9 0}}$ \\
\cline { 2 - 4 } Total & $\mathbf{3 5 3 3 , \mathbf { 8 9 }}$ & $\underline{\mathbf{3 4 4 5 , 7 3}}$ & $\underline{\mathbf{3 3 3 3 , 9 6}}$ \\
\hline
\end{tabular}

$8 \%$ cost decline (strong pro-privatization scenario)

\begin{tabular}{lrrr} 
Consumers & 3165,30 & 2897,21 & 2615,83 \\
Government & 505,84 & 510,70 & 510,35 \\
Producers & 368,29 & 457,90 & 541,90 \\
\cline { 2 - 4 } Total & $\mathbf{4 0 3 9 , \mathbf { 4 3 }}$ & $\underline{\mathbf{3 8 6 5 , 8 1}}$ & $\mathbf{3 6 6 8 , 0 8}$ \\
\hline
\end{tabular}

Given previously stated assumptions, we can conclude that all agents seem to have benefited from the OTE privatization and the liberalization of the telecommunications markets. Perhaps government is not affected as much as consumers group but we have not including here the effects of the sale itself. Using equal (unit) social weights, consumers always have positive gains an d seem to be the most benefited group. Consumers seem to have experienced some losses during the first years immediately after privatization, but liberalization seem to have had a strong positive effect on the gains attributed to OTE's consumers. We can say that OTE's historical background prices fall in a significant pattern after 2001, so it would be expected that consumers attracted a big share of total efficiency gains after this year. Perhaps producers are affected the least but here we have not included all benefits for all life time project period (infinite), but only for 1998-2009.

SCBA is an analytical framework for systematically identifying the extent and distribution of costs and benefits of privatisation, based on comparing the factual outcome with a counterfactual scenario of continued state ownership. We have thought that this approach was better than most empirical privatization research that simply has compared data 'before' and 'after' privatization usually for a limited number of years. In contrast to most empirical research on privatization, liberalization, and regulation it focuses on welfare changes for different agents and not just on productivity and profitability or other business performance indicators. If we have had access to a more detailed database about the telecommunication sector, we would have been able to produce more accurate estimates and evaluate more precisely the Greek telecommunications reform impact in comparison with the British or North American experience. 


\section{References}

Athreya. 1996. India's telecommunications policy. Elsevier science. 1996, Vol. 20, 1, pp. 11-22.

—. 1999. India's telecommunications policy. Elsevier Sience. 1, 1999, Vol. 20, pp. 11-22. Telecommunications Policy.

Bordman. 2007. 2007.

Bortolotti, Bernardo, et al. 2002. Privatization and the sources of performance improvement in the globa ltelecommunications industry. Telecommunications Policy. 2002, Vol. 26, 5-6, pp. 243-268.

Boyland, O and Nicolleti, G. 2002. Regulation, market structure and performance in telecommunication. s.l. : OECD, 2002.

Boyland, Olivier and Nicolett, i Giuseppe. 2000. Regulation, market structure and performance in telecommunication. s.1.: OECD, 2000.

Constantelou, N and Ypsilantis, D. 2001. Regulatory Reform in the Tecommunications Industry in Greece. OECD. 2001.

D' Souza, Juliet, Megginson, William and Nash, Robert. 2001. Determinants of Performance Improvements in Privatized Firms: The Role of Restructuring and Performance Improvements in Privatized Firms: The Role of Restructuring and Corporate Governance. University of Oklahoma : s.n., 2001.

Dia, Magueye, N' Guessan, Tchetche and Paul, Jean -. 2002. Telecommunications Sector Reforms in Senegal. s.l. : World Bank, 2002.

Domah and Pollitt. 2001. 2001.

Fink Carsten, Mattoo Aaditya and Rathindran Randeep. 2003. An assessment of telecommunications reform in developing countries. 2003, Vol. 15, 4, pp. 443-466. Information Economics and Policy.

Florio, M. 2003. Does privatization matter? The long term Performance of British Telecom over 40 years. Fiscal Studies. 2003, Vol. 24, 2, pp. 197-234.

Galal, A, et al. 1994. The Welfare Consequences of Selling Public Enterprises. oxford : World Bank, 1994.

Gary, Madden and Jason, Savage Scott and Ng. 2003. Asia - Pacific Telecommunications Liberalization and Productivity Performance. Australian. 2003, Vol. 42, 1, p. 91.

Green and Daniel, Mc. 1998. 1998.

Green Paper. Comission, European. 1987. 1987. p. 52.

Haggarty, L, Shirley, M. and Walsten. 2003. Telecommunications reform in Ghana. s.l. : World Bank, 2003.

Heracleou, s Loizos. 2001. State Ownership, Privatization and Performance in Singapore: An Exploratory Study from a Strategic Management Perspective. Asia Pacific Journal of Management. 2001, 18, pp. 69-81.

Jones, L, Tandon, P. and Vogelsang, I. 1990. Selling Public Enterprises: A Cost -Benefit Methodology. Cambridge : MIT Press, 1990.

Kallianiotis, Ioannis N. 2007. Global Uncertainty, European Unemployment, and the Warning American Competitive Games. s.l. : University of Scranton, 2007. p. 51.

Karamanis, K and Georgopoulos, A. 2008. Telecommunication Deregulation: The case of Greece. 2008.

Karamanis, Kostas. 2006. The Financial and operating performance of privatized firms in Teleommunications: The case study of OTE. Mibes. 2006.

Laffont, Jean - Jacques and N' Guessan, Tchetche. 2003. Telecommunications Reform in Cote d' Ivoire. s.l. : World Bank, 2003.

Lampropoulou, M. 2009. Public utilities reform in Greece: Privatization, market liberazation and implications for citizens as consumers. 2009.

Lee, C. 2002. Telecommunications Reforms in Malaysia», Annals of Public \& Cooperative Economics. Blackwell Publishing, 2002, Vol. 73, 4, p. 521.

Lee, Sangjin and Ypsilantis, Dimitris. 2002. Regulatory Reform in the Telecommunications Industry in Poland. s.1. : OECD, 2002.

Luke, Haggarty, Mary, Shirley and Scott, Wallsten. 2003. Telecommunications Reform in Ghana. s.l. : World Bank, 2003.

Madden, Gary, Savage, Scott and Ng, Jason. 2003. Asia - Pacific Telecommunications Liberalization and Productivity Performance. Australian Economics Papers. Blackwell Publishing, 2003, Vol. 42, 1, p. 91.

Megginson William, Nash Robert $\square \square \square$ Van Randenborgh Matthias. 1994. The Financial and Operating Performance of Newly Privatized Firms: An International Empirical Analysis. The Journal of Finance. 1994, Vol. 49, 2, pp. 403-452.

Min, Wonki and Ypsilantis, Dimitris. 1999. Regulatory Reform in the Telecommunications Industry in the Netherlands. s.1.: OECD, 1999.

Min, Wonki. 1999. Regulatory Reform in the Telecommunications Industry in Japan. s.l. : OECD, 1999.

Newberry, D and Pollit, M. 1997. The Restructuring and Privatisation of Britain's CEGB-was it worth it? The Journal of Industrial Economics. 1997, Vol. 45, pp. 269-303.

Newberry, S. 2001. Public sector accounting, a common reporting framework? Australian accounting revie. 2001, Vol. 11, 1, pp.

2-7.

OECD. 2001. 2001.

OTE SEC filings. OTE. 2009. 2009.

OTE, SEC Filings. OTE. 2005. 2005. 
Pagoulatos. 2005. The Politics of Privatization:Redrawing the Public-Private Boundary. West European Politics. 2005, Vol. 28, 2, pp. 358-380.

Parker. 2004. Editorial: Lessons from privatization. Economic Affairs. 2004, Vol. 24, p. 2.

Sanford, Gutierrez Luis \& Berg. 2000. Telecommunications liberalization and regulatory governance: lessons from Latin America. Elsevier Science. 2000, Vol. 24, 10-11, pp. 865-884.

Sato, Kyoko and Ypsilantis, Dimitris. 2000. Regulatory Reform in the Telecommunications Industry in Denmark. s.1.: OECD, 2000.

Sinha. 1996. The political economy of India's telecommunications. Elsevier science. Telecommunications policy, 1996, Vol. 20, 1, pp. 23-38.

Sinha, Nikhil. 1996. The political economy of India's telecommunications reforms. Elsevier Sience. 1996, Vol. 20, 1, pp. 23-38.

Stigler. 1971. The theory of Economic Regulation. Bell Journal of economics and management science. 1971, 3, pp. 3-18.

Wallsten, Scott. 200. An Econometric Analysis of Telecom Competition,Privatization and Regulation in Africa and Latin America. Journal of Industrial Economics. 200, Vol. 49, 1, p. 1.

Walter, Ingo and Smith, Roy. 2000. High Finance in the Euro-Zone. London : Financial Times, 2000.

Wilson\&Zhou. 2001. Telecommunications deregulation and subadditive costs: Are local telephone monopolies unnatural. s.1. :

Elsevier Science, 2001. pp. 909 - 930. International Journal of Industrial Organization.

Wilson, J. 1984. The politics of regulation. James Q Wilson. New York : s.n., 1984. pp. 357-394.

Wonki, Ypsilantis Dimitris and Min. 2000. «Regulatory Reform in the Industry - United Kingdom. 2000.

Xavier, Patrick and Ypsilantis, Dimitris. 2001. Regulatory Reform in the Telecommunications Industry in Czech Republic. 2001. -. 2000. Regulatory Reform in the Telecommunications Industry in Spain. s.1. : OECD, 2000.

Yamada, Takashi and Ypsilantis, Dimitris. 2001. Regulatory Reform in the Telecommunications Industry in Ireland. s.1. : OECD, 2001.

Ypsilantis, Dimitris and Min, Wonki. 2001. Regulatory Reform in the Telecommunications Industry in Italy. s.1. : OECD, 2001. Ypsilantis, Dimitris. 2000. Regulatory Reform in the Telecommunications Industry-Canada. s.1. : OECD, 2000.

- 2000. Regulatory Reform in the Telecommunications Industry-United Kingdom. s.1.: OECD, 2000.

Zhou, Wilson \&. 2001. 2001. 